\title{
ANALISIS PENINGKATAN KEPUTUSAN KUNJUNGAN WISATAWAN MELALUI PROMOSI, PRASARANA DAN PELAYANAN
}

\author{
Imaduddin $^{1}$, Budiandriani ${ }^{2}$, Andi Faisal Bahari ${ }^{*}{ }^{3}$ \\ 1,2,3* Departement of Management, Faculty of Economics and Business; Universitas Muslim Indonesia, \\ Urip Sumoharjo Street, Km. 5 Makassar, South Sulawesi \\ e-mail: ${ }^{1}$ imaduddin.imaduddin@ @umi.ac.id, ${ }^{2}$ budiandrianimt@umi.ac.id, ${ }^{*}{ }^{3}$ faisal.bahari@umi.ac.id
}

\begin{abstract}
Abstrak
Penelitian ini bertujuan untuk mengetahui pengaruh Promosi, Prasarana dan Pelayanan Terhadap Keputusan Kunjungan Wisata Pantai Seruni di Kabupaten Bantaeng. Pendekatan penelitian ini menggunakan pendekatan kuantitatif, sampel yang digunakan yaitu berjumlah 100 orang sampel dengan kriteria yang telah ditentukan. Dan selanjutnya model analisis data yang digunakan adalah analisis regresi linear berganda yang diolah menggunakan SPSS. Berdasarkan hasil penelitian yang dilakukakan menunjukkan bahwa secara simultan promosi, prasarana dan pelayanan secara bersama sama berpengaruh terhadap keputusan kunjungan wisatawan. Kemudian secara parsial kualitas promosi dan pelayanan berpengaruh terhadap kunjungan wisatawan, sedangkan kualitas prasarana tidak berpengaruh terhadap keputusan kunjungan wisatawan.

Kata kunci: Promosi, Prasarana, Pelayanan, Keputusan Kunjungan Wisatawan.
\end{abstract}

\begin{abstract}
The aim of this study is to see how promotion, infrastructure, and services influence people's decisions to visit Seruni Beach in Bantaeng Regency. This study takes a quantitative approach, with 100 samples chosen based on predetermined parameters. After that, SPSS was used to process the data analysis model, which was multiple linear regression analysis. According to the findings of the study, tourism visit decisions are influenced by promotion, facilities, and services all at the same time. Then, to some extent, the standard of promotion and service influences tourist visits, while the quality of infrastructure has no bearing on tourist visit decisions.
\end{abstract}

Keywords: Promotions, Infrastructure, Services, Tourist Visit Decisions

\section{PENDAHULUAN}

Kebanyakan orang bepergian atau berwisata untuk bersenang-senang seperti tujuan wisatawan pada umumnya. Tetapi tidak jarang orang memanfaatkan waktunya untuk belajar sekaligus menambah wawasan, pengetahuan, dan keterampilan tentang sesuatu hal. Dengan kata lain mereka datang ke suatu tempat tidak saja hanya untuk melihat-lihat tetapi memiliki tujuan yang lebih dari itu, yaitu sesuatu yang berharga yang tidak mungkin didapatinya di tempat asalnya.

Pariwisata merupakan bagian dari sektor industri di Indonesia yang dianggap memiliki prospek cerah, dan mempunyai potensi yang sangat besar untuk dikembangkan. Potensi tersebut didukung oleh kondisi-kondisi alamiah seperti letak dan keadaan geografis (lautan dan daratan sekitar khatulistiwa), lapisan tanah yang subur dan panoramis (akibat ekologi geologis), serta berbagai flora dan fauna yang memperkaya isi daratan dan lautan. (Pramusita \& Sarinastiti, 2018)

Perkembangan industri pariwisata merupakan suatu fenomena yang menarik, meskipun pariwisata juga merupakan sektor yang sangat sensitif terhadap perubahan yang terjadi baik secara internal maupun eksternal yang sangat berpengaruh terhadap jumlah dan minat wisatawan untuk mengunjungi suatu negara, wilayah/provinsi maupun daerah. Industri tersebut secara langsung memberikan dampak terhadap 
ekonomi, sosial dan budaya. Pemasar dapat mengembangkan industri dan memahami latar belakang yang memengaruhi seorang konsumen dalam menentukan keputusan berkunjung ke sebuah spot wisata. (Bahari \& Ashoer, 2018).

Industri pariwisata sesungguhnya tidak berdiri sendiri, tetapi merupakan serangkaian perusahaan yang menghasilkan barang dan jasa yang berbeda satu dengan lainnya. (Mulyati \& Afrinata, 2018). Di dalamnya terdapat berbagai faktor penentu, seperti produk wisata yang unik, adanya promosi (komunikasi pemasaran) yang lancar dan terus menerus kepada pasar sasaran, serta memahami motivasi perjalanan wisatawan dan sebagainya. Obyek wisata Pantai Seruni contohnya yang saat ini keberadaannya sangat cocok karena juga berada di tengah tengah kota Kabupaten Bantaeng yang mudah dijangkau untuk dijadikan sebagai obyek wisata. Kabupaten Bantaeng terdapat banyak obyek wisata baik wisata alam, budaya, maupun wisata lainnya. Terkhusus pada wisata pantai seruni yang beralamat di jl. Seruni, Kelurahan Pallantikang, Kecamatan Bantaeng, Pantai seruni ini merupakan kawasan hasil reklamasi sepanjang satu setengah kilometer dan merupakan spot utama yang menghubungkan dua wilayah kabupaten yang berbeda sehingga tidak jarang banyak pengunjung dari berbagai daerah baik lokal maupun mancanegara.

Guna menunjang kelangsungan kunjungan wisatawan pada obyek wisata Pantai Seruni ini, pengelola memberi fasilitas dan prasarana yang memadai dalam memudahkan pemberian pelayanan yang bermanfaat pada para pengunjung yang memungkinkan proses kepariwisataan dapat berjalan lancer. Obyek Pantai Wisata merupakan pengelolaan konstelasi obyek wisata pantai dan pelayanannya yang diharapkan mampu memberikan kepuasan bagi para pengguna layanan wisata pantai (Taruna, 2012). Sejalan dengan penelitian (Jajang, et, al. 2018) Semua hal yang berkaitan dengan pariwisata serta layanan jasa wisata tersebut ditujukan untuk mampu memenuhi permintaan wisatawan akan kepuasan berpariwisata yang pada akhirnya pengelola mengharapkan mampu meningkatkan jumlah wisatawan yang berkunjung di Pantai Seruni.

Penelitian yang dilakukan oleh (Kusumawardhani, et, al. 2016) menyatakan Rendahnya tingkat kunjungan wisatawan dikarenakan masih kurangnya promosi yang dilakukan oleh pemerintah setempat. Hal itu bisa dibuktikan misalnya dalam keikutsertaan kegiatan pameran, Kabupaten Pemalang hanya sekali mengikuti kegiatan pameran dalam setahun. Pengeluaran wisatawan di Kabupaten Pemalang juga masih rendah, karena industri pariwisata di Kabupaten Pemalang belum begitu berkembang, sama halnya dengan yang dihadapi pengelola wisata Pantai Seruni belum menemukan bentuk promosi yang dapat diandalkan guna meningkatkan jumlah kunjungan wisatawan, hasil penelitian ini akan membantu pengelola secara langsung terkait upaya yang dapat ditempuh dalam melakukan kegiatan promosi utamanya informasi yang akan disampaikan kepada calon pengunjung.

Beberapa informasi yang dibutuhkan calon wisatawan (Sofia, et, al. 2020) seperti ketersediaan dan jenis sarana prasarana penginapan selama ini tidak dapat terinformasikan secara luas karena hanya didapatkan apabila calon wisatawan menghubungi pengelola penginapan yang mereka ketahui saja. Selain itu, informasi kepadatan pengunjung adalah sangat penting bagi calon wisatawan dalam menyusun jadwal kunjungan sehingga mereka benar-benar dapat menikmati liburannya, serta bagi pengelola wisata akan dapat memperkirakan jumlah dan jenis sarana dan prasarana yang harus mereka sediakan sehingga mampu memberikan pelayanan terbaik bagi wisatawan. 
Faktor prasarana dalam penelitian ini merupakan fasilitas untuk kebutuhan masyarakat pada umumnya dan pembangunannya merupakan suatu usaha yang besar, karena itu biasanya ditangani oleh pemerintah dengan menggunakan keuangan Negara. Tidak hanya ketersediaan aksesibilitas serta prasarana saja yang dibutuhkan untuk mendukung kegiatan pariwisata, sarana juga menjadi salah satu faktor dalam menentukan kemajuan suatu objek wisata (Sumarabawa, et, al. 2013). Penelitian ini diharapkan dapat memberikan tambahan Informasi tentang keputusan wisatawan berkunjung di Pantai Seruni Kabupaten Bantaeng dan bisa digunakan sebagai dasar untuk menentukan kebijakan-kebijakan dalam pemerintahan terutama pada Dinas Pariwisata dalam meningkatkan jumlah pengunjung pantai seruni.

\section{METODE PENELITIAN}

Data yang dikumpulkan dalam penelitian akan digunakan untuk memecahkan masalah yang ada sehingga data-data tersebut harus benar-benar dapat dipercaya dan akurat. Data yang digunakan dalam penelitian ini diperoleh melalui metode kuesioner yaitu teknik pengumpulan data yang dilakukan dengan cara memberi seperangkat pertanyaan atau pernyataan tertulis kepada responden untuk dijawab. Sampel dalam penelitian ini berjumlah 100 responen. Rancangan penelitian adalah penelitian kuantitatif dimana disusun berdasarkan hasil kusioner dan data dari perusahaan. Variabel yang digunakan dalam penelitian ini terdiri dari faktor-faktor yang mempengaruhi dan keputusan wisatawan. Analisis data adalah pengolahan data yang diperoleh dengan menggunakan analisis rumus atau dengan aturan-aturan yang ada sesuai dengan pendekatan penelitian. Analisis data dilakukan dengan tujuan untuk menguji hipotesis dalam rangka penarikan kesimpulan. Adapun metode analisis data yang digunakan dalam rangka penelitian ini dengan melakukan Analisis regresi berganda digunakan untuk mengetahui pengaruh antara variabel bebas terhadap terikat. Persamaaan regresi linear berganda dengan dua variabel bebas yaitu:

$$
Y=a+b 1 X 1+b 2 X 2+b 3 X 3+e
$$

Dimana:

$$
\begin{aligned}
& \mathrm{a}=\text { konstanta } \\
& \mathrm{b} 1, \mathrm{~b} 2, \mathrm{~b} 3 \quad=\text { koefisien regresi } \\
& \mathrm{Y}=\text { keputusan wisatawan } \\
& \mathrm{X}_{1}=\text { promosi } \\
& \mathrm{X}_{2}=\text { prasarana } \\
& \mathrm{X}_{3}=\text { pelayanan } \\
& \mathrm{e} \quad=\text { standar error }
\end{aligned}
$$

\section{HASIL DAN PEMBAHASAN Hasil}

Berdasarkan outout hasil olah data yang dilakukan, pertama-tama dilakukan Uji normalitas untuk melihat apakah nilai residual terdistribusi normal atau tidak karena model regresi linier yang baik adalah memiliki nilai residual yang terdistribusi normal. Uji normalitas dalam penelitian ini dilakukan dengan bantuan SPSS statistic 23 dengan alatnya kolmogorovSmirnov. Pengujian normalitas dilakukan dengan membandingkan nilai signifikan. Jika angka sig. Uji K-S > 0,05 maka dapat disimpulkan bahwa residual menyebar normal, sebagaimana gambar di bawah ini. 


\section{Gambar 1. Uji Normalitas}

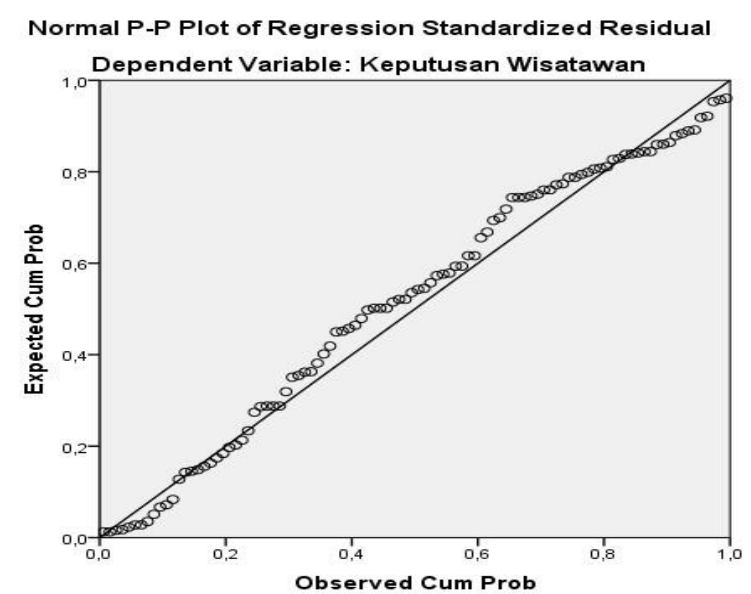

Selanjutnya dilakukan Pengujian scara simultan yang dimaksudkan untuk mengetahui bagaimana variabel independent yang terdiri dari variabel promosi, prasarana, pelayanan secara simultan (bersama-sama) berpengaruh terhadap variabel dependent keputusan wisatawan pantai seruni Kabupaten Bantaeng. Dari hasil uji anova atau F-test, diperoleh F-hitung $=8.134>$ Ftabel $=0,05$ artinya terdapat pengaruh secara signifikan dari promosi, prasarana, dan pelayanan secara simultan (bersama-sama) terhadap keputusan kujungan wisatawan.

Tabel 2. Hasil Uji Simultan (Uji f) ANOVA

\begin{tabular}{|ll|r|r|r|r|r|}
\hline & & Sum of Squares & & & & \\
Model & & Df & Mean Square & F & Sig. \\
\hline 1 & Regression & 5,078 & 3 & 1,693 & 8,134 &, $000^{\mathrm{b}}$ \\
& Residual & 19,979 & 96 &, 208 & & \\
& Total & 25,057 & 99 & & & \\
\hline
\end{tabular}

a. Dependent Variable: Keputusan Wisatawan

b. Predictors: (Constant), Pelayanan, Promosi, Prasarana

Sumber: Data Diolah, 2020

Selanjutnya, dilakukan uji t berdasarkan koefisien regresi pada tiap variabel independen terhadap variabel dependen dan didapatkan hasil sebagai berikut:

Tabel 2. Hasil Uji Parsial (Uji t)

Coefficients $^{\mathrm{a}}$

\begin{tabular}{|c|c|c|c|c|c|c|c|}
\hline & \multirow{2}{*}{ Model } & \multicolumn{3}{|c|}{ Unstandardized Coefficients } & Standardized Coefficients & \multirow{2}{*}{$\mathrm{t}$} & \multirow{2}{*}{ Sig. } \\
\hline & & B & & Std. Error & Beta & & \\
\hline \multirow{4}{*}{1} & (Constant) & & 3,827 & 2,708 & & 1,148 & \\
\hline & Promosi & & ,251 & ,070 & ,325 & 3,567 & ,001 \\
\hline & Prasarana & & ,342 & , 146 & ,230 & 2,338 & ,021 \\
\hline & Pelayanan & & 141 & , 109 & ,655 & 4,579 & .000 \\
\hline
\end{tabular}


Sumber: Data Diolah, 2020

Berdasarkan tabel di atas diperoleh hasil sebagai berikut: 1) Berdasarkan hasil penelitian yang menguji pengaruh promosi terhadap keputusan wisatawan maka nilai thitung $=3,567$ dengan tingkat signifikasi sebesar 0,001 lebih kecil di bandingkan dengan tingkat $\mathrm{a}=5 \%$. Hasil ini menunjukan bahwa secara perhitungan statistik promosi berpengaruh positif dan signifikan terhadap keputusan wisatawan. Dengan demikian hipotesis diterima, 2) Berdasarkan hasil penelitian yang menguji prasarana terhadap keputusan wisatawan maka nilai t-hitung $=2,338$ dengan tingkat signifikasi sebesar 0,021 lebih besar dibandingkan dengan tingkat $\mathrm{a}=5 \%$. Hasil ini menunjukan bahwa secara perhitungan statistik prasarana tidak berpengaruh dan tidak signifikan terhadap keputusan wisatawan. Dengan demikian Hipotesis ditolak. dan 3) Berdasarkan hasil penelitian yang menguji pengaruh pelayanan terhadap keputusan wisatawan maka nilai t-hitung $=4,579$ dengan tingkat signifikasi sebesar 0,000 lebih besar dibandingkan dengan tingkat $\mathrm{a}=5 \%$ hasil ini menujukan bahwa secara perhitungan statistik pelayanan berpengaruh positif dan signifikan terhadap keputusan wisatawan. dengan demikian $\mathrm{H} 1$ ditolak. Hasil keseluruhan menunjukan bahwa variabel promosi mempunyai pengaruh positif dan signifikan terhadap keputusan kunjungan wisatawan secara simultan dan parsial. Sedangkan variabel prasarana dan pelayanan tidak mempunyai pengaruh terhadap keputusan kunjungan wisatawan. Diketahui dari ketiga variabel bebas tersebut yang paling dominan pengaruhnya adalah pelayanan karna memiliki nilai koefisien beta dan t-hitung paling besar.

\section{Pembahasan}

\section{Pengaruh Promosi Terhadap Keputusan Kunjungan Wisatawan}

Hasil pengujian hipotesis pertama menunjukkan bahwa variabel Promosi berpengaruh positif dan signifikan terhadap keputusan kunjungan wisatawan. Hasil ini memberikan gambaran bahwa wisatawan yang telah berkunjung diwisata Pantai Seruni Kabupaten Bantaeng telah mendapatkan informasi yang lengkap fasilitas yang akan diperoleh. Keadaan ini menjadi masukan bagi pengelola dan juga masih banyak lagi tugas yang bisa dilakukan oleh pemerintah Kabupaten Bantaeng dalam melakukan berbagai kegiatan promosi yang pada akhirnya akan meningkatkan angka calon pengunjung baru tiap tahunnya, hal ini sejalan dengan penelitian yang dilakukan oleh (Ramadhan, 2016) Promosi berpengaruh terhadap keputusan kunjungan wisatawan.

\section{Pengaruh Prasarana Terhadap Keputusan Kunjungan Wisatawan}

Hasil pengujian hipotesis kedua menunjukkan bahwa faktor Prasarana tidak berpengaruh terhadap keputusan wisatawan untuk berkunjung ke pantai seruni. Temuan ini termasuk langka dan juga sekaligus menjadi bukti bahwa pengunjung yang sudah pernah datang menikmati wisata pantai tahu betul apa yang mereka butuhkan dengan mengesampingkan sarana yang memang telah memadai dan memberikan mereka kenyamanan ketika menghabiskan waktu di pantai seruni.

Beberapa kasus mengenai penelitian terdahulu mengenai prasarana ini justru berbeda di tempat wisata lainnya dengan menitikberatkan pada ketersediaan dan pengembangan prasarana yang memadai dalam meningkatkan jumlah kunjungan wisata khusunya pantai, seperti pada penelitian yang dilakukan (Bian, et, al. 2016) bahwa Aksesibilitas atau jalan yang menuju ke objek wisata Pantai Sulamadaha kondisinya masih terbilang baik dengan bahan material aspal namun yang menjadi masalah yaitu 
jalan atau akses di dalam lokasi wisata yang masih belum di tata dengan baik sehingga perlu penanganan khusus bagi pengelola untuk memperbaiki prasarana aksesbilitas di dalam lokasi wisata Pantai Sulamadaha, termasuk penelitian yang dilakukan (Narendra W, et, al. 2018) Prasarana wisata yang akan dikembangkan pada lokasi studi wisata Pantai terdiri atas prasarana umum saja. Proses analisa dilakukan berdasarkan hasil kuisoner yang bersumber dari para pengunjung yang datang pada tempat wisata Pantai yang kemudian dianalisis menggunakan analisa perhitungan skala untuk mengetahui kebutuhan prasarana wisata yang dibutuhkan bagi pengunjung wisata Pantai Sipelot Kab. Malang.

\section{Pengaruh Pelayanan Terhadap Keputusan Kunjungan Wisatawan}

Hasil pengujian hipotesis ketiga menunjukkan bahwa faktor pelayanan berpengaruh positif dan signifikan terhadap keputusan wisatawan untuk berkunjung ke pantai seruni. Terlihat bahwa pengelola yang berkolaborasi dengan pemerintah daerah telah menunjukkan kapabilitasnya dalam hal pelayanan sehingga mendapatkan respon yang baik dan pengalaman yang menyenangkan bagi para pengunjung. Hal ini sejalan dengan penelitian yang dilakukan (Handayani \& Dedi, 2017), Kualitas Pelayanan berpengaruh signifikan terhadap Peningkatan Jumlah Kunjungan. Dalam penelitian ini diketahui bahwa dimensi empati pada variabel kualitas pelayanan memiliki hubungan yang sangat kuat terhadap dimensi kepuasan dalam variabel peningkatan jumlah kunjungan di Pelabuhan Muncar Banyuwangi, sama halnya dengan penelitian (Jordan A, et, al. 2019) menyatakan terdapat korelasi yang kuat dari variabel pelayanan terhadap kunjungan wisata edukasi Sentul fresh Indonesia.

\section{KESIMPULAN}

Promosi yang dilakukan pihak pengelola wisata pantai seruni yang berkolaborasi dengan pemerintah Kab. Bantaeng berupaya meningkatkan promosi ke arah yang lebih baik dan tepat sasaran kedepannya dengan berbagai instrumen yang bisa digunakan dan pada akhirnya mampu lebih meningkatkan jumlah pengunjung. Pada bagian prasarana dalam penelitian ini bahwa hasilnya menunjukkan beberapa permasalahan yang mungkin bisa memberi dampak kurang baik kedepannya pada pihak pengelola, tetapi di luar dari hasil penelitian yang memang terjadi di lapangan memberikan pelajaran berarti dimana prasarana tidak berpengaruh signifikan, dapat disimpulkan bahwa pengunjung yang sudah lebih kali kedua berkunjung sudah faham betul kecukupan prasarana yang ada di lokasi wisata. Bagian pelayanan yang mana pihak pengelola dan pemerintah daerah telah berupaya maksimal memberi kesan dan pengalaman yang baik kepada pengunjung, terbukti bahwa dari hasil penelitian ini menunjukkan pengaruh yang signifikan terhadap keputusan kunjungan wisatawan, juga ditunjang dari kesadaran masyarakat setempat memberikan dampak yang positif bagi pengunjung.

\section{SARAN}

Penelitian ini berkontribusi dalam peningkatan jumlah Kunjungan Wisata pantai seruni dan sangat mengharapkan perhatian dari pengelola dan pemerintah daerah Kabupaten Bantaeng dengan melihat potensi yang sangat besar untuk bisa lebih berkembang dan membuka cakrawala dunia tentang manfaat yang bisa diperoleh pengunjung dengan senantiasa membenahi faktor-faktor penentu yang telah dilakukan 
pada penelitian ini dan pada akhirnya memberi benefit pada pengelola, pemerintah daerah dan masyarakat luas.

\section{UCAPAN TERIMA KASIH}

Penulis mengucapkan terima kasih kepada Lembaga Penelitian dan Pengembangan Sumberdaya (LP2S) Universitas Muslim Indonesia dan Dekan Fakultas Ekonomi dan Bisnis UMI yang telah memberi dukungan financial terhadap penelitian ini.

\section{DAFTAR PUSTAKA}

Bahari, A. F., \& Ashoer, M. (2018). Pengaruh Budaya, Sosial, Pribadi Dan Psikologis Terhadap Keputusan Pembelian Konsumen Ekowisata. Jurnal Minds: Manajemen Ide dan Inspirasi, 5(1), 68-78.

Bian, A. P. P., Waani, J. O., \& Poluan, R. J. (2016). Analisis Ketersediaan Prasarana Dan Sarana Untuk Objek Wisata (Studi Kasus: Kawasan Wisata Pantai Sulamadaha Di Kota Ternate). Spasial, 3(3), 38-46.

Handayani, E., \& Dedi, M. (2017). Pengaruh promosi wisata bahari dan kualitas pelayanan terhadap peningkatan jumlah kunjungan wisatawan di Pelabuhan Muncar Banyuwangi. Jurnal Wira Ekonomi Mikroskil: JWEM, 7(2), 151-160.

Jajang, M., Yulisetiarini, D., \& Hadi, P. (2018). Analisis Tingkat Kepuasan Konsumen Berdasarkan Kualitas Pelayanan pada Pengunjung Objek Wisata Pantai Pulau Merah Kabupaten Banyuwangi. e-Journal Ekonomi Bisnis dan Akuntansi, 5(2), 189-193.

Jordan, A., Herdiana, N., \& Satyajaya, W. (2019). Analisis Kualitas Pelayanan dan Strategi Pengembangan Wisata Edukasi Sentulfresh Indonesia. Operations Excellence, 11(1), 1-11.

Kusumawardhani, D., Rostyaningsih, D., \& Rengga, A. (2016). Implementasi Kebijakan Promosi Potensi Wisata (Pantai Widuri) Kabupaten Pemalang. Journal of Public Policy and Management Review, 5(2), 491-501.

Mulyati, Y., \& Afrinata, M. (2018). Analisis Pengaruh Strategi Bauran Pemasaran Terhadap Minat Berkunjung Kembali Pada Destinasi Wisata Pantai Carocok Painan Kabupaten Pesisir Selatan (Studi Kasus Pada Wisatawan Domestik). Jurnal Akuntansi, Ekonomi Dan Manajemen Bisnis, 6(2), 191-200.

Narendra, W. (2018). Identifikasi Kebutuhan Sarana Dan Prasarana Wisata Berdasarkan Persepsi Pengunjung Di Pantai Sipelot Kabupaten Malang (Doctoral dissertation, Institut Teknologi Nasional Malang).

Pramusita, A., \& Sarinastiti, E. N. (2018). Aspek sosial ekonomi masyarakat lokal dalam pengelolaan Desa Wisata Pantai Trisik, Kulonprogo. Jurnal Pariwisata Terapan, 2(1), 14-25. 


\section{AkMen}

Ramadhan, F. (2016). Pengaruh kualitas layanan dan promosi terhadap keputusan berkunjung ke tempat wisata pantai Samudera Baru. Value: Journal of Management and Business, 1(1).

Sofia, L. A., Hidayat, A. S., \& Zain, M. A. (2020). Optimalisasi Media Sosial Sebagai Sarana Promosi Wisata Pantai Asmara. Jurnal Pengabdian Al-Ikhlas Universitas Islam Kalimantan Muhammad Arsyad Al Banjary, 5(2).

Sumarabawa, I. G. A., Wesnawa, I. G. A., \& Astawa, I. B. M. (2015). Ketersediaan Aksesibilitas Serta Sarana dan Prasarana Pendukung Bagi Wisatawan Di Daerah Wisata Pantai Pasir Putih, Desa Prasi, Kecamatan Karangasem. Jurnal Pendidikan Geografi Undiksha, 3(3).

Taruna, M. S. (2015). Analisis Peningkatan Minat Wisata Melalui Peningkatan Pelayanan Pada Obyek Wisata Pantai Widuri Kabupaten Pemalang. Pena Jurnal Ilmu Pengetahuan dan Teknologi, 22(1). 